\title{
Accounting Conservatism Alleviates Firm's Investment Efficiency: An Evidence from China
}

\author{
Naveed Razzaq, Zhang Rui, Zou Donghua \\ School of Accountancy, Jiangxi University of Finance and Economics, Nanchang, China \\ Email address: \\ naveed.razzaq@hotmail.com (N. Razzaq),jxufechen@163.com (Zhang Rui),dhzhou1982@hotmail.com (Zou Donghua)
}

\section{To cite this article:}

Naveed Razzaq, Zhang Rui, Zou Donghua. Accounting Conservatism Alleviates Firm's Investment Efficiency: An Evidence from China. International Journal of Business and Economics Research. Vol. 5, No. 4, 2016, pp. 85-94. doi: 10.11648/j.ijber.20160504.12

Received: May 30, 2016; Accepted: July 14, 2016; Published: July 15, 2016

\begin{abstract}
This study examined the association of accounting conservatism with investment efficiency, and its effects on investment efficiency by mitigating firms from under and over investments of listed companies in China (2002 to 2013). First, we find the existence of conservatism in accounting practices of Chinese firms, later to hypothesize that how conservatism improves investment efficiency to alleviate under or over investment stresses. Thus, our findings confirmed that accounting conservatism improves investment efficiency of Chinese firms by mitigating under (over) investments. Furthermore, significant correlation existed for investment efficiency with free cash flow and corporate governance such as CEO duality and percentage of board members. In robust test, we find conservatism reduces the CEO duality and top one shareholder tunneling effect which may cause agency problem.
\end{abstract}

Keywords: Accounting Conservatism, Investment Efficiency, Overinvestment, Underinvestment

\section{Introduction}

Accounting conservatism got importance after long debate between researchers, regulators and standards setters regarding its economic consequences. Further, Financial Accounting Standards Board (FASB) and International Accounting Standards Board (IASB) decided to pay importance to faithfulness and neutrality in financial statements rather than conservatism. Researchers raised the importance of conservatism and argued its association with higher quality financial reporting. Many researchers [1, 2, 3, 4] are of the view that accounting conservatism is still existing in our accounting system since long. Recently [5] explained the importance of accounting conservatism and its economic consequences. Their research illuminated that conservatism still debatable and researchable topic.

A huge accounting literature about conservatism and investment decision or managers investment incentives reveal two main views, one is related to under (over) investment, while another is mangers incentives and agency cost [6]. Accounting conservatism can constraint the manager's role and decrease agency problems, which may possibly cause firms to gain overinvestment. On the contrary, accounting conservatism causes an abnormal or poor investment incentives for mangers that ultimately waived positive net present value (NPV) projects leading to underinvestment [3, 7 , 8]. Conservatism is expected to give access to external funds at lower cost and decrease firm's underinvestment chances in absence of agency problems [9]. Conservatism controls managers from manipulation in accounting, provide access to other sources and gives timely warning signals to corporate governance to avoid any future loss $[7,10,11,12]$ examined firm's utilization of conservatism approach may have huge capital investment. Conservatism may also cause an underinvestment problem particularly negative relation of conservatism with underinvestment [13]. Similarly, [14] failed to find any positive relation of conservatism and investment efficiency in of Tunisian economy. Our study explains conservatism from both prospective, first is more efficient investment by the firm, and second the causes or improvements in investment efficiency (under-overinvestment) by controlling managerial decision. This paper will contribute to examine that conservatism causes (reduce) on the firms for under or overinvestment. Conservative firms are less likely under or overinvest at good investment level [15]. Timely loss recognition restricts the manager to peruse less risky projects, discourage investment 
in negative net present value projects, indirectly may affect manger incentives and cause firm's underinvestment. [13] argued that conservatism may have adverse effects on manager's investment incentives and encourage them to ignore positive net present value projects. Further, [8] explained that most risky projects tend to be negative projects, so conservatism may risk-aversive manger to give up risky projects even though keep positive net present value for investors. In addition, conservatism or timely economic loss recognition discipline may intimate managers to avoid negative but net present value projects.

This research may help to improve how accounting conservatism is used to indicate the empirical results or to identify some issues and to debate in emerging market. Accounting conservatism and investment efficiency relation infers the economic consequences of conservatism in China. Furthermore, this research will play an important role in the accounting area and accounting research development market, as well as will add to the overall literature about accounting conservatism. In line with prior research, this paper shows with different data sample, conditional conservatism reduces investment efficiency, to support and enhance the academic study.

This study is continuation of the existing literature of conservatism and investment efficiency or investment decisions. Previously it was [16, 17, 18, 13, 15, 19] stated that accounting conservatism may causes (improves) investment efficiency and firms under (over) investment, mangers investment incentives and resolve agency problems. This empirical research investigates that conditional conservatism alleviates the firms from under or over investments issues particularly in China A-share listed companies in Shenzhen and Shanghai stock exchanges. This study data sample consists of 20040 observations from 2002 to 2013. However, we found that conservatism still alive in accounting system of China. Timely loss recognition to mitigates firms from (under) overinvestment in China [20, 21]. Firms overinvested by mangers excessive use of free cash flow in negative NPV projects and involvement in personal benefits, become cause of agency problem. China is taking serious steps to resolve agency problems, firm's over-investment and excessive use of free cash flow [22]. Conditional conservatism improves investment efficiency by giving access to external funds and disciplined managerial investment decisions to ignore risky projects which associated with negative net present values, rather encourages managers to invest in positive NPV projects, hence conservatism is mostly demanded by investors.

\section{Literature Review}

In current study, we reviewed the existing literature with special focus on the relationship between conditional accounting conservatism and investment efficiency. Recently [11] demonstrated the financial losses with timely loss recognition shows the presence of information a symmetric as a reaction. All these factors are projected jointly to alleviate the investment efficiency, even conservatism is being criticised. However, conservatism has persisted in accounting practices of the world and gradually increased since many decades. The present study explains the accounting conservatism in investment efficiency. Accounting conservatism is generally known as recognising the expenses and liabilities of the firm in a timely manner rather than recognise revenue and asset only verifiable. It was defined that conservatism is as recognition of bad news (losses) as compares the good news (gains) [1, 3].

The present study investigates that accounting conservatism alleviates the firms from over investment. Prior literature depicted the impacts of accounting conservatism on investment efficiency (over/under investment). Accounting conservatism may caused a reduction in the agency cost conflicts regarding investment [22, 23] and asymmetric information about both lenders and borrowers reducing the cost of capital [24, 15]. Furthermore, [13] argued that accounting conservatism causes dysfunctional investment incentives for managers and found a negative relationship between accounting conservatism, future operating performance and future investments. It was also reported that conditional conservatism can increase the firm investment efficiency by a timely prediction of losses in income statements [15, 19]. [10] found that more conservatism in the firm predicts the more future profitability measures like a gross profit margin, cash flows and less special items charges.

The high accounting measures leads to a good investment efficiency process and conservatism is a characteristic of the good quality accounting. Many others investigated the conservatism at a country level, which associated with investment efficiency $[25,26]$. The literature related to investment efficiency may influence to raise the quality of reporting. In addition, conservatism has positive effect on firm's corporate governance and resolve agency problem.

In context of China, accounting conservatism is more demanding because of ownership structures and corporate governance. China ownership structure is concentrated without an isolation of ownership structure that is not common in China due to concentrated ownership [27]. Chinese government is an ultimate owner of Chinese firms and has managerial power [28]. [29] stated that because of strong government controls in China, the important implications of corporate governance were ignored. Conservatism is beneficial for enterprises by investment decisions, reducing cost of capital, improving corporate governance, reducing agency cost conflict and as a result enhancing firm's values. Corporate governance is increasing parallel with economic improvements in China [30]. So we can speculate that accounting conservatism improves corporate governance and resolve agency cost problems. Another aim of this study is to highlight conservatism association with corporate governance and investment efficiency, and investment efficiency influence by corporate governance.

Modern investment theory proposed by [31] showed that firms tend to invest in new projects with a higher return rate, 
while less financing cost means less investment. On the other side conservatism overcomes over investment within short time. [32] investigated that conservatism can ease the over investment by manger's prospective. Furthermore, conservative financial reporting approach is beneficial for the firm and increases the cash flow, alleviates firms from overinvestment and also resolves the agency cost problem. It was also reported that accounting conservatism alleviates firms from under (over) investments by giving access to the external resources and controlling managers opportunities and behaviour [33, 34, 15, 19, 35]. Many other workers are of the view that accounting conservatism improves the investment efficiency in Chinese firms by mitigating firms from under (over) investment [16,17, 18], while accounting conservatism has positive association with investment efficiency. Similarly, we find significant positive relationship of accounting conservatism and investment efficiency herein.

This empirical research investigates the association of conservatism and investment efficiency, according to which conditional conservatism alleviates the firms from under (over) investments by improving investment efficiency. Current paper aimed to successfully predict through our results that the accounting conservatism consequences on investment efficiency in China, and we found that accounting conservatism has positive relation with investment efficiency. In addition, this paper also found that accounting conservatism mitigating firms from (under) overinvestments while controlling manager's investment decisions in China. Conditional conservatism eases the firm from under and over investments, finally leading to resolve agency problems, in fact by improving corporate governance in firms. Herein, this study further raised certain question that how conditional accounting conservatism effects to improves investment efficiency by reducing under-over investments of a firms? Does this study find economic consequences of conservatism and importance in emerging market needs to unravel?

Present empirical study will further focused on empirical design and sample, which will be discussed in the coming sections,

\section{Development of Hypothesis}

Previously it was reported that the association of accounting conservatism and investment efficiency, showed that conservatism has significantly positive (negative) impact on investment efficiency. According to [3], who stated that accounting conservatism improves firm investment efficiency. By comparing our results with previous reports $[36,16,17,18$, $15,19,13]$ we found that the relationship of accounting conservatism with investment efficiency showed that accounting conservatism surely improved investment efficiency. We proposed that conservatism alleviates (causes) firms under-overinvestments. Furthermore, [15, 19] found more conservative firms are less over or underinvestment. Following these studies, we first hypothesized that conditional conservatism alleviates investment efficiency, though these are consistent with previous reports and depicted the conditional accounting conservatism effects on the reduction of overinvestment.

There existed some general views about the conditional conservatism and investment efficiency e.g. positive and negative association between conditional accounting conservatism and investment efficiency. In addition, more conservative firms are less likely to over and underinvestment [15]. On the contrary, conditional accounting conservatism causes the firm to over or under investment [13]. [14] also found negative association between conservatism and investment association in emerging market in context of Tunisia.

Conditional accounting conservatism timelines information asymmetry (timely recognition of bad news (losses), then good news (gains)) is increasing investment efficiency by decreasing the over and under investment, while lessen investment in negative NPV projects. Further, accounting conservatism alleviates investment efficiency by providing access to the firms to finance (external finance) and reducing the cost of new funds for the new investment. In short, give the access to invest in new projects for the sake of reducing the underinvestment.

Primarily we proposed three hypotheses and confirmed the consistency with prior studies while examining the relationship between conservatism and investment efficiency.

H1: Greater the accounting conservatism, greater the investment efficiency

H2: Accounting conservatism alleviates firms from underinvestment

H3: Accounting conservatism alleviates firms from overinvestment

A huge literature documented about the conservatism and investment efficiency (over or underinvestment) similar to our hypotheses. It was examined that conservative accounting choices effecting investment decisions and limiting firms overinvestment and underinvestment [26, 37, 15, 19]. This paper particularly will focus on the conditional accounting conservatism, in time information asymmetry effect the investment efficiency, which may ease firms from under-overinvestment.

\section{Research Design}

The section will describe the empirical models under examination for the conservatism relationship with investment efficiency. Our model specification is based on prior studies on similar lines $[25,17,18,15,19,13]$. First, we measure the conservatism by using a model proposed by [1] with slight modifications [38] at year firm level and then examine the relation of conservatism with investment efficiency, including the sample size used for this study.

\subsection{Measurements of Accounting Conservatism and Investment Efficiency}

In the past two methods remained very popular to measure conservatism and based on accounting measures. First method, asymmetric timeliness of earnings originally 
introduced by [1], while the second was accrual based method coined by [2]. However, these conservatism measure methods are based on accounting practices of firm performance. In this study, first we measure the conditional conservatism (C-Score) type based on measure [1], however further developed by [38]. [1] investigated earnings which are associated with bad news (negative return) and good news (positive return), further, defined conservatism as the more strict verifiability requirements for the recognition of gains relative to losses into accounting earnings [1]. Consistently, we do practiced the estimation following standard model [1] and examine incremental timeliness coefficient that increased conditional conservatism (CCONS). These specification and estimation help to find the existence of accounting conservatism in China, which further led to estimate CCONS with investment efficiency using control variables.

[39] Richarson model was used to measure investment efficiency (over or underinvestment). Accounting techniques and information are important to solve information asymmetry problems. Recently it was said that monitoring the senior managers and valuations of the future cash flows may facilitated by accounting information [40, 41]. These are accounting related effects that projected to improve firms' investment decisions cause to increase the firm values. We measured the residual for firm investment efficiency. If residual is more than zero is overinvestment and vice versa underinvestment, however if residual is zero then investment is efficient.

\subsection{Conditional Accounting Conservatism Association with Investment Efficiency}

The association of accounting conservatism and investment efficiency are dependent on conservatism which may cause (reduces) firms from under and over investments [17, 18, 15, 19] also measured investment cash flow sensitivities that can reflect either financing constraints, an excess of cash and or agency problems. Aforesaid that over tests is based on prior studies which allow analysing the influences of accounting choices for firms to get rid of under-overinvestment. Moreover, conservatism improves investment efficiency by mitigating firms from underinvestment, hence providing external financing and overinvestment to limit manager's investment decisions. Furthermore, conservatism reduces the agency conflicts between managers and investors via reduction of asymmetric information. We portrayed a following model to summarize the effects of conditional conservatism on investment efficiency.

$$
\begin{gathered}
\mathrm{INVR}_{\mathrm{it}}=\mathrm{CCONS}_{\mathrm{it}}+\mathrm{FCashf}_{\mathrm{it}}+\mathrm{MBRS}_{\mathrm{it}}+\mathrm{DPOF}_{\mathrm{it}}+\mathrm{TOP} 1_{\mathrm{it}}+\mathrm{DU} \\
\mathrm{AL}_{\mathrm{it}}+\mathrm{SIZE}_{\mathrm{it}}+\mathrm{MNGRSH}_{\mathrm{it}}+\mathrm{e}_{\mathrm{it}} \\
\mathrm{INVR}_{\mathrm{it}}<0=\mathrm{CCONS}_{\mathrm{it}}+\mathrm{FCashf}_{\mathrm{it}}+\mathrm{MBRS}_{\mathrm{it}}+\mathrm{DPOF}_{\mathrm{it}}+\mathrm{TOP}_{\mathrm{it}}+\mathrm{D} \\
\mathrm{UAL}_{\mathrm{it}}+\mathrm{SIZE}_{\mathrm{it}}+\mathrm{MNGRSH}_{\mathrm{it}}+\mathrm{e}_{\mathrm{it}}
\end{gathered}
$$

$\mathrm{INVR}_{\mathrm{it}}>0=\mathrm{CCONS}_{\mathrm{it}}+\mathrm{FCashf}_{\mathrm{it}}+\mathrm{MBRS} \%_{\mathrm{it}}+\mathrm{DPOF}_{\mathrm{it}}+\mathrm{TOP} 1_{\mathrm{it}}+\mathrm{D}$ $\mathrm{UAL}_{\mathrm{it}}+\mathrm{SIZE}_{\mathrm{it}}+\mathrm{MNGRSH}_{\mathrm{it}}+\mathrm{e}_{\mathrm{it}}$
Where, Equation (a) dependent variable INVR is investment efficiency residual which we measured using Richardson, (2006) model, equations (b) and (c) are representing, INVR $<0$, INVR $>0$ underinvestment and over investment respectively, underinvestment if INVR is less than 0 and overinvestment of INVR greater than $0 . \mathrm{MBRS} \%$ is percentage of board members, DPOF is dividend payoff, TOP1 is top one shareholder of the firm, DUAL is CEO duality, if chairman and CEO are same is equal to 1 otherwise 0 . SIZE is firm size and MNGRS is manager's shareholder in the firms. In addition details of all variables are given in appendix (c).

To analyses the effect of accounting adoptions in reducing over and underinvestment, and net effects, we claimed that conditional accounting conservatism alleviates investment efficiency. This paper also depicts conservatism increases cash flows, save firms from under-investment, stabilize firms to overinvest by controlling in time investment decisions. In addition, conservatism also reduces the information asymmetry between managers and investors, hence, accounting conservatism decreases the agency problem by examining corporate governance variables with conservatism.

\subsection{Data Selection}

We aimed in this paper to examine conservatism relation with investment efficiency by using accounting data at CSMAR database. Most of the data was extracted from annual reports of A-Share listed companies. Agency of China Securities Regulation Commission (CSRC) is controlling all listed companies and tackles listed companies information such as stock issues, annual or semi-annual reports. We collected data of all non-financial companies spanning 2002-2013. The data regarding all listed companies registered in the Shenzhen and Shanghai stock exchanges was collected, but only non-financial companies data was selected because of variable company structure, investment environment and accounting practices of financial companies. This penal data consists of 20040 observations with control and calculated variables (see Table A1 in Appendix C).

Table 1 descriptive statistics of control variables in this study. This depicts the variables descriptive analysis of full sample size of 20040 firms. Descriptive table is showing mean, median, Standard deviation (Std. Div), and Min \& Max values, respectively and individual variable no. of observations. CCONS mean values is -0.07 which is lower than prior western research such as $[10,15,19]$ documented higher mean value of conservatism. We can say that conditional accounting conservatism in China is lower than west. In addition, [42] found lower mean value of conservatism and documented that conservatism level lower than in USA. In line with this statement that accounting conservatism level is lower, [43] analysed and found same in context of Malaysian context. From these results we can conclude that conservatism in emerging market is less than developed market. Mean and median values $3.24,-0.004$ respectively which is smaller than [15] documented in context of Europe. 
Table 1. Descriptive statistics.

\begin{tabular}{lllllll}
\hline Variables & No. Obs & Mean & Median & Std. Div. & Min & Max \\
\hline CCONS & 21601 & -0.07586 & -0.05173 & 0.649745 & -78.914 & 21.53009 \\
INVR & 21166 & $3.24 \mathrm{E}-07$ & -0.00424 & 0.160414 & -9.36947 & 2.010183 \\
FCashf & 20608 & 0.04333 & 0.044268 & 0.098507 & -4.26956 & 1.019217 \\
MBRS\% & 9098 & 0.330339 & 0.333333 & 0.156259 & 0.052632 & 1 \\
MNGRSH & 20609 & 0.042439 & $2.51 \mathrm{E}-06$ & 0.137588 & 0 & 3.89907 \\
DPOF & 20609 & 0.065356 & 0 & 0.129708 & 0 & 3.997 \\
SIZE & 20608 & 21.6001 & 21.40935 & 1.377862 & 11.34833 & 30.57112 \\
\hline
\end{tabular}

Note: The table describes descriptive statistics for the main control variables in research. All variables data calculated from end of fiscal year from 2002 to 2013. CCONS is conditional conservatism which is calculated from [1] model which modified by [38], INVR investment efficiency residual which is calculated from [39], FCashf is free cash flow of the firm, MBRS\% is percentage of members, MNGRSH is managers share, DPOF is refer dividend payoff and Size is log of firm total assets. For further detail see Table A1. Variables explanation in appendix C.

Table 2 shows the Spearmen correlation between variables. Before we analyze the regression analysis, examine correlation of variables between each other. We applied spearmen correlations which don't have assumption of data normal distribution. However we assumed that our data is normally distributed. Correlation table shows that CCONS is significantly related with all variables. However, CCONS negatively correlated with INVR which is against our hypotheses. We are expecting positive relation between conservatism and investment efficiency. Free cash flow, dividend payoff, CEO Duality and manager's share are positively significant correlated with cost of capital. In line with INVR others variables like member's percentage and Top1 shareholder also negative significant correlated with conservatism. In addition, investment efficiency (INVR) significantly correlated with firm size, dividend payoff and free cash flow. CEO Duality (DUAL), TOP1 shareholder and managers share are significantly associated with CCONS (conditional conservatism), which shows that conservatism influence on agency problem. Members percentage (MBRS\%) is also negatively significant with CCONS which reflect that small board size is more conservative for small firms which consistent with prior research. Our all most of independent variables are significant and not highly correlated except MNGRSH variable which is highly correlated with conservatism. However, the existence of only one variable in our variables model, we could not say that multicollinearity exit in the model. In addition, we employ variance inflation factor (VIF) test to detect multicollinearity in the model, which is explained in Appendix (D). We find VIF value 2.61 which is not bigger but if VIF is 10 or great than 10 then collinearity problem in model. As a result, VIF test shows that no multicollinearity in control variables.

Table 2. Spearmen correlation of control variables.

\begin{tabular}{|c|c|c|c|c|c|c|c|c|c|}
\hline & CCONS & INVR & FCashf & MBRS\% & DPOF & TOP1 & DUAL & SIZE & MNGRSH \\
\hline CCONS & 1 & & & & & & & & \\
\hline INVR & $-0.0768^{*}$ & 1 & & & & & & & \\
\hline FCashf & $0.0696^{*}$ & $0.0610^{*}$ & 1 & & & & & & \\
\hline MBRS \% & $-0.0262 *$ & 0.0039 & -0.016 & 1 & & & & & \\
\hline DPOF & 0.0774* & $0.0268 *$ & $0.2065^{*}$ & -0.0111 & 1 & & & & \\
\hline TOP1 & $-0.1019^{*}$ & -0.0092 & $0.0849 *$ & $-0.0268 *$ & $0.1394 *$ & 1 & & & \\
\hline DUAL & $0.0575^{*}$ & -0.0092 & -0.0171 & 0.0026 & $-0.0683^{*}$ & $-0.0798^{*}$ & 1 & & \\
\hline SIZE & $-0.1312^{*}$ & $0.0272 *$ & 0.0790 * & -0.006 & $0.1113^{*}$ & $0.1783^{*}$ & $-0.0691^{*}$ & 1 & \\
\hline MNGRSH & $0.0963 *$ & -0.0153 & $0.0633^{*}$ & -0.0131 & $0.3096^{*}$ & $-0.0747 *$ & $0.0313^{*}$ & $-0.0413 *$ & 1 \\
\hline
\end{tabular}

Note: Spearmen Correlation shows significant * at $5 \%$ level.

\section{Empirical Finding and Results}

In this paper, the descriptively analyze and examine correlation of independent variables. Accordingly, we mentioned above, through regression model of research, association of conservatism and investment efficiency. We analyze through this simple model the association and explain finding and results. Table 3 shows the regression analysis and infer the results and finding of the paper.

As old and recent empirical studies examined conservatism and investment efficiency and documented that accounting conservatism improves investment efficiency, in line with prior reported literature $[25,15,17,18,19]$ find that accounting conservatism improves investment efficiency. We find that accounting conservatism is positively significant with investment efficiency at $1 \%$ level (coeff. 0.0407 and t-stat 22.90). Our results are consistent with prior research that conservatism increases the free cash flow (FCashf) which is also positively significant with conservatism and these finding shows conservatism improves firm investment efficiency (save firm from underinvestment's) [25]. In line of the same stream of research, current paper are examining association of conservatism and investment efficiency. We provide evidence by measuring conservatism for each year for firms from [38] and measure investment efficiency and under (over) investments from [39]. In addition, we found dividend payoff (DPOF), TOP1 manager share and CFO duality (DUAL) are negatively significant at $1 \%$ level $($ coeff. $=-0.1$, $\mathrm{t}$-value $=$ 
-10.6), (coeff. $=-0.02, \mathrm{t}$-value $=-3.5$ ) and (coeff. $=-0.009$, $\mathrm{t}$-value $=-3.3)$ respectively with investment efficiency. These findings show that investment efficiency improves by decreasing dividend payoff and prominent shareholder shares or incentives. Further, same designation of chairman and CEO or CEO duality is negatively associated with investment efficiency. CEO duality and separation of CEO and chairman influences the firm performance because agency problem intensity is higher when CEO and chairman are on the same position. Prior research reported that companies become more valuable if CEO and chairman of board are having separate positions [44, 45]. Furthermore, separation of chairman and CEO positions reduces CEO incentives or compensation [46]. We infer that CEO duality is not beneficial for investment efficiency and may be cause of agency problem.

Table 3. Regression Analysis.

\begin{tabular}{llll}
\hline & Investment efficiency (INVR) & Under-investment INVR<0 & Over-investment INVR>0 \\
\hline CCONS & 0.0407 & 0.0445 & -0.0142 \\
& $(22.90)^{* * *}$ & $(22.88)^{* * *}$ & $(-4.35)^{* * *}$ \\
FCashf & 0.69046 & 0.9211 & -0.0503 \\
& $(74.96)^{* * *}$ & $(84.83)^{* * *}$ & $(-4.38)^{* * *}$ \\
MBRS\% & 0.02156 & 0.0408 & -0.0137 \\
& $(3.80)^{* * *}$ & $(5.37)^{* * *}$ & $(-2.49)^{* * *}$ \\
DPOF & -0.1022 & -0.1629 & 0.0235 \\
& $(-10.64)^{* * *}$ & $(-13.18)^{* * *}$ & $(2.37)^{* * *}$ \\
Top1 & -0.0231 & -0.0149 & -0.0067 \\
& $(-3.46)^{* * *}$ & $(-1.67)^{*}$ & $(-1.04)$ \\
Dual & -0.0098 & -0.0145 & 0.0014 \\
& $(-3.27)^{* * *}$ & $(-3.53)^{* * *}$ & $(0.48)$ \\
Size & 0.00453 & 0.00694 & -0.0069 \\
& $(4.54)$ & $(5.59)^{* * *}$ & $(-8.37)^{* * *}$ \\
MNGRSH & 0.00358 & 0.0072 & -0.00298 \\
Intercept & $(0.27)$ & $(0.45)$ & $(-0.24)$ \\
& -0.0162 & -0.0155 & 0.1685 \\
Year and Industry fixed effect & $(-0.82)$ & $(-5.62)^{* * *}$ & $(9.11)^{* * *}$ \\
No. Obs. & yes & yes & Yes \\
R-square & 19948 & 11208 & 8735 \\
\hline
\end{tabular}

Note: This table explains the regression analysis of 20040 A-Share listed firms registered in Shanghai and Shenzhen stock exchange. CCONS is conditional conservatism which is calculated from [1] model which modified by [38], INVR investment efficiency residual which is calculated from [39], FCashf is free cash flow of the firm, MBRS\% is percentage of members, MNGRSH is managers share, DPOF is refer dividend payoff and Size is log of firm total assets. Here, the symbols $* * *, * *,{ }^{*}$ presents significance at the $1 \%, 5 \%$, and $10 \%$ levels, respectively and the values in parentheses are t-value. All the variables are explained in Table 1 in appendix (c).

According to former researchers, conservatism mitigates firm from underinvestment and overinvestment. In line with our Hypotheses (H2 and H3) our results are also consistent with this statement that accounting conservatism alleviates firms' under and over investments. This study hypothesis (H2 and $\mathrm{H} 3$ ) argue that asymmetric timeliness of earnings alleviate firms from under (Over) investments. However, by obeying these hypotheses, we found significantly negative relation with underinvestment and significantly positive association with overinvestments at level $1 \%$ (coeff. $=0.044, \mathrm{t}$-value $=$ $22.88)$ and (coeff. $=-0.014$, t-value $=-4.35$ ) respectively. Table 4 regression analyses show that underinvestment $(\mathrm{INVR}<0)$ is positively explained by free cash flow (FCashf) and (MBRS\%) and board member percentage at level $1 \%$ with coeff. $=0.92$ $\mathrm{t}$-value $=84.83$ and coeff. $=0.04$, $\mathrm{t}$-value $=5.37$ respectively. These findings show that increase in free cash flow and members' percentage in board is a decreasing cause to firm's underinvestment. Further, the underinvestment has negative association with dividend payoff, TOP 1 manager shareholder shares and CEO duality at significant level 1\%, 10\% and $1 \%$ respectively. Table 3 column three shows that enhancing dividend payoff and prominent shareholders' shares decreases underinvestment. The CEO duality increases, then, may be cause for underinvestment. Further, Table 3 column four overinvestment (INVR $>0)$ shows that accounting conservatism decreases firms from overinvestment but we also find that by increasing dividend payoff and decreasing board members percentage caused firms to overinvest. Free cash flow has negative association with overinvestment which shows that by increasing free cash flow then overinvestment will decrease. As prior researchers [25, 15] showed that free cash flow increases investment efficiency and improves firms from underinvestment. In other words, conservatism enhances or reduces free cash flow among investments. In addition, Table 3 shows that board member percentage (MBRS\%, is also referring as board size) is positively associated with investment efficiency and underinvestment but negatively associated with firm's overinvestment. These findings infer that board is efficient in working and its monitoring mechanism may cause to shrink firms from under and over investments. The more conservative firms improve investment efficiency by giving less dividend payoff. 
This paper also conducts the robust test to verify results. We employ 2SLS model which is developed by [47] to do robust analysis. In alternative evaluation of conservatism and investment efficiency, we found same significant results. Moreover, we found that conservatism is significantly negatively associated with CEO duality and TOP1 shareholder share. It shows that conservatism may reduce the agency problem by decreasing CEO duality and prominent shareholder tunnelling in the firm; such as [48] examined Chinese economy and reported that large shareholders are tunnelling or propping minority shareholders in China. They are analysed by different shareholding ratios.

\section{Conclusion}

The literature about conservatism is a still important and researchable for researchers. Researchers [11, 38, 15, 13, 5, 49, 19, 50] explained economic importance and consequences, and some explained relationship of conservatism with investment efficiency. However, our findings and results are consistent with our hypotheses and prior research.

We found a positive relationship of accounting conservatism and investment efficiency. We found that conditional accounting conservatism improves firm's investment efficiency. Furthermore, the positive association of conservatism and underinvestment which shows that conservatism reduces the under-investment by enhancing free cash flow and monitoring manager's decision. According to our findings, board member's percentage is positively associated with conservatism and underinvestment, which predicts that conservatism, alleviates firms from underinvestment by good governance mechanism. This study finds that conservatism is negatively significant with overinvestment and shows that conservatism mitigates firms from over investment. Conservatism improves investment efficiency in China and mitigates firms from under (over) investment by increasing (decreasing) free cash flow, member's percentage in board and dividend payoff. In addition, those firms which are big in size are less likely to under and over invest. Further, conservatism resolves agency problem and underinvestment problem by decreasing the TOP1 shareholder tunnelling to the minor shareholders and CEO duality from firms in China. In sum, we conclude this study by highlighting economic consequences of accounting conservatism and by proving that accounting conservatism alleviates investment decision or efficiency by reducing firms from under-overinvestments and reduces the agency problem in Chinese firms.

In sum, this study may influence educational researchers, standard setters and supervisory bodies. Research of accounting conservatism has positive role and benefits in emerging economy. In future, by extending the same vein of study, it will explore in detail that how conservatism mitigates firms from under (over) investments. Furthermore, it will be more interesting to put more emphasis on conditional conservatism, corporate governance and investment efficiency by selecting a multiple period of data sample and associations of variables.

\section{Appendix}

A. Conditional conservatism measure model:

In this study, first we measure the conditional conservatism (C-Score) type which is based on basu model measured by (Basu , 1997), however further developed by khan and Watts (2009). Basu (1997) investigate that earnings associated with bad news (negative return) than good news (positive return).

$$
\mathrm{NIt}=\beta_{0}+\beta_{1} \mathrm{DRt}+\beta_{2} \mathrm{Rt}+\beta_{3} \mathrm{DRt} \times \mathrm{Rt}
$$

Where

$\mathrm{NI}_{\mathrm{t}}=$ Net Income at year $\mathrm{t}$

$\mathrm{R}_{\mathrm{t}}=$ Annual Return at year $\mathrm{t}$

$\mathrm{DR}_{\mathrm{t}}=$ is dummy variable, its equal to one if $\mathrm{R}_{\mathrm{t}}$ is negative, 0 otherwise

In this study, first we measure the conditional conservatism (C-Score) type which is based on Basu model developed by (Basu, 1997), however further modified by khan and Watts (2009). Basu (1997) investigated that earnings associated with bad news (negative return) than good news (positive return). The timeliness of earnings reflects good news and bad news and conservatism at firm level. Ball, Kothari and Nikolaev (2009) employed Basu (1997) model to measure conservatism and stated that this model is able to capture the cross-sectional changes in conditional conservatism (cited in Lara et al., 2010). Khan and Watts (2009) the timeliness of good news refers as G-Score for each year and bad news refers as C-Score and CCONS for firm each year.

G-Score $=$ CCONS $=$ bad news $=\beta_{3}=\mu_{0}+\mu_{1} \operatorname{Size}_{\mathrm{i}}+\mu_{2} \mathrm{MB}_{\mathrm{i}}+\mu_{3} \operatorname{Lev}_{\mathrm{i}}(\mathrm{A} 2)$
C-Score $=$ Good news $=\beta_{4}=\lambda_{0}+\lambda_{1} \operatorname{Size}_{\mathrm{i}}+\lambda_{2} \operatorname{MB}_{\mathrm{i}}+\lambda_{3} \operatorname{Lev}_{\mathrm{i}}$ (A3)

Where $\mu_{\mathrm{i}}$ and $\lambda_{\mathrm{i}} \mathrm{i}=0$ to 3 are firm constant but it's vary over time. Size is size of the firm and MB is market to book value, Lev is referring as leverage of firm i. In above equations c-Score is measuring conservatism of firm year or increasing bad news timeliness. (Khan and Watts, 2009) C-Score and G-Score are varying across firms and year Characteristics (Size, MB and Lev) and increasing variation over time in $\mu_{\mathrm{i}}$ and $\lambda_{\mathrm{i}}$. Conservatism is increasing in CCONS (which referred as C-Score in Khan and Watts, (2009)). By substituting $\beta 3$ and $\beta_{4}$ in Basu, (1997) model $X_{i}=\beta_{1}+\beta_{2} D_{i}+\beta_{3} R_{i}+\beta_{4} D_{i} \times R_{i}$ $+\mathrm{e}$ or in equation (A1), we got equation (A4). The annual cross-sectional regression model used to calculate C-Score and G-Score is:

$\mathrm{Xi}=\beta 1+\beta 2 \mathrm{Di}+\mathrm{Ri}\left(\mu_{0}+\mu_{1} \operatorname{Size}_{\mathrm{i}}+\mu_{2} \mathrm{MB}_{\mathrm{i}}+\mu_{3} \operatorname{Lev}_{\mathrm{i}}\right)+\operatorname{DiRi}\left(\lambda_{0}\right.$
$+\lambda_{1}$ Size $\left._{\mathrm{i}}+\lambda_{2} \mathrm{MB}_{\mathrm{i}}+\lambda_{3} \mathrm{Lev}_{\mathrm{i}}\right)+(\delta 1 \operatorname{Sizei}+\delta 2 \mathrm{M} / \mathrm{Bi}+\delta 3 \mathrm{Levi}+$
$\delta 4 \mathrm{DiSizei}+\delta 5 \mathrm{DiM} / \mathrm{Bi}+\delta 6 \mathrm{DiLevi})+\mathrm{e}_{\mathrm{i}}$

B. Investment efficiency measure model:

To measure the investment efficiency we imply the Richardson (2006) model to find the investment efficiency (over or underinvestment). We measure the residual for firm investment efficiency. If residual more than zero is overinvestment, vice versa underinvestment, however if residual is zero then investment is efficient (if this happen then misspecification in model). 
$\operatorname{INVEST}_{i, t}=\alpha+\beta_{1}$ Growth $_{i t-1}+\beta_{2}$ lev $_{i t-1}+\beta_{3}$ cash $_{i t-1}+\beta_{4}$ size $_{i t-1}$

$+\beta_{5}$ Age $_{i t-1}+\beta_{6}$ return $_{i t-1}+\beta_{7} I N V_{i, t-1}+\varepsilon_{i, t}$

$\operatorname{INVEST}_{\mathrm{i}, \mathrm{t}}=$ Investment expenditure , $\mathrm{I}$ is the firm in $\mathrm{t}$ Growth $_{\mathrm{i}, \mathrm{t}-\mathrm{l}}=$ Growth opportunity

$\operatorname{lev}_{\mathrm{i}, \mathrm{t}-\mathrm{l}}=$ leverage ((sum of the book value of total debt and book value of total equity)

C. Variables Explanations cash $_{\mathrm{i}, \mathrm{t}-1}=$ is the balance of cash, short term investments deflated by total assets measured at the start of the year.

size $_{\mathrm{i}, \mathrm{t}-1}=\log$ of the total assets

$\operatorname{Age}_{i, t-1}=\log$ of the number of the years firm has been listed.

return $_{\mathrm{i}, \mathrm{t}-1}=$ return of the previous year investment

$\mathrm{E}_{\mathrm{i}, \mathrm{t}}=$ residual

Table A1. Variables explanation.

\begin{tabular}{ll}
\hline Variables & Explanation and Calculation \\
\hline CCONS & Conditional accounting conservatism calculated from Basu (1997) which is further modified by Khan and Watts (2009) \\
INVR & Investment efficiency residual which is calculated from Richardson (2006) \\
FCashf & Free Cash flow which is extracted from cash flow statements or cash flow from operations \\
MBRS\% & Member's percentages which is calculated as no. directors divided by no of audit committee members. \\
MNGRSH & Mangers shares such as Directors, Chief Executive Officer and their spouses and minor children. This data extracted from annual report. \\
DPOF & Dividend payoff and calculated as total dividend pay-out divided by total no. of shares holders. \\
SIZE & Firm size is natural log of total assets of firm. \\
\hline
\end{tabular}

\section{Variance Inflation factor Test of data normal distribution}

Table A2. Variance inflation factor test.

\begin{tabular}{lll}
\hline Variables & VIF & 1/VIF \\
\hline CCONS & 1.00 & 0.998186 \\
FCashf & 1.04 & 0.960879 \\
MBRS $\%$ & 1.03 & 0.970873 \\
TOP1 & 1.10 & 0.905066 \\
SIZE & 1.09 & 0.914444 \\
DPOF & 1.07 & 0.934933 \\
MNGRSH & 1.03 & 0.972738 \\
DUAL & 1.03 & 0.973033 \\
Mean VIF & 1.05 & 0.93 \\
\hline
\end{tabular}

\section{References}

[1] Basu, S. (1997) The Conservatism Principle and the Asymmetric Timeliness of Earnings. Journal of Accounting and Economics 24, 3-37.

[2] Givoly, D., and C. Hayn, 2000, The changing time-series properties of earnings, cash flows and accruals: has financial reporting become more conservative? Journal of Accounting and Economics 29, 287-320.

[3] Watts, R. (2003a) Conservatism in Accounting Part I: Explanations and Implications, Accounting Horizons, 17: 207-221.

[4] Grambovas, A., B. Giner, and D. Christodoulou, 2006, Earnings conservatism panel data evidence from the European Union and the United States, Abacus 42, 354-378.

[5] Ruch, G. and Taylor, G. (2014) Accounting conservatism and its effects on financial reporting quality: a review of the literature, working paper.
[6] Ball, R., \& Shivakumar, L. (2005). Earnings Quality in U.K. Private Firms. Journal of Accounting and Economics 39, 83-128.

[7] Guay, W., \& Verrecchia, R. E. (2007). Conservative disclosure. Working paper, University of Pennsylvania.

[8] Roychowdhury, S. 2010. Discussion of: Acquisition profitability and timely loss recognitionby J. Francis and X. Martin. Journal of Accounting and Economics, 49: 179-183.

[9] Chen, X. D, \& Huang, D. S. (2007). Corporate governance and conservatism. Securities Market Herald, 3, 10-17.

[10] Ahmed, A. S. and S. Duellman (2007a). Evidence on the role of accounting conservatism in monitoring managers' investment decisions. Working paper, Texas A\&M University.

[11] LaFond, R. and R. L. Watts. (2008). The information role of conservatism. The Accounting Review, 83(2): 447-478.

[12] Jackson, S. B., X. Liu and M. Cecchini. 2009. Economic consequences of firms' depreciation method choice: evidence from capital investments. Journal of Accounting and Economics, 48(1): 54-68. 
[13] Tao M. (2014). Accounting conservatism and corporate investments: a review of the literature, working paper, Washington University in St. Louis.

[14] Asma Hucine. (2013). Does accounting conservatism affect firm investment efficiency in an Jmerging market?: Evidence from Tunisian context. African Journal Accounting, Auditing and Finance, Vol. 2, No. 3.

[15] Garcia Lara, J. M., B. Garcia Osma, and F. Penalva, (2010). Conditional conservatism and firm investment efficiency, Working paper (Universidad Carlos III de Madrid, Madrid).

[16] LIU Hongxia, S. L. (2011). An Empirical Study on Accounting Conservatism and Investment Efficiency. Journal of Audit \& Economics, vol. 5.

[17] Tian Chun-xiao, Y. F. (2013). Accounting Conservatism and Corporate Investment Efficiency:A Literature Review and Expectation. Jiangsu Commercial Forum, vol. 4.

[18] Gui-hua, Wang. (2013). Accounting Conservatism and Enterprise Investment Efficiency-Empirical Evidence from Chinese A-share Listed . Journal of Tongling University, vol. 2.

[19] Garcia Lara, J. M., B. Garcia Osma, and F. Penalva, (2015). Conditional conservatism and firm investment efficiency, Working paper.

[20] Jensen, M. J. 1986. Agency costs of free cash flow, corporate finance and takeovers. American Economic Review, 76(2): 323-329.

[21] Stulz, R. M. (1990). Managerial discretion and optimal financing policies. Journal of Financial Economics, 26, 3-27. Xin, Q., Zheng, G. and Yang, D. (2007), Corporate group, government control and investment efficiency, Journal of Financial Research, No. 10, pp. 123-42 (in China).

[22] Ball, R. (2001). Infrastructure Requirements for an Economically Efficient System of Public Financial Reporting and Disclosure. Brookings-Wharton Papers on Financial Services, 2001(1), 127-169. doi: 10.1353/pfs.2001.0002

[23] Ahmed, A. S., \& Duellman, S. (2007). Evidence on the role of accounting conservatism in corporate governance. Journal of Accounting and Economics, 43, 411-437.

[24] Biddle, G., and G. Hilary, (2006). Accounting quality and firm-level capital investment, The Accounting Review 81, 963 982.

[25] Bushman, R. M., J. D. Piotroski, and A. J. Smith, (2007). Capital allocation and timely accounting recognition of economic losses, Working paper (University of Chicago, Chicago, IL).

[26] Lin, T. P., Hutchinson, M. R., \& Percy, M. (2009). The role of the audit committee and institutional investors in constraining earnings management: evidence from Chinese firms listed in Hong Kong. Proceedings of Accounting \& Finance Association of Australia \& New Zealand Annual Conference 2009. Accounting and Finance Association of Australia and New Zealand (AFAANZ), Adelaide, Australia.

[27] Lin, T. P. (2011). Corporate governance mechanisms and earnings management in transitional countries - evidence from Chinese listed firms (Doctoral dissertation). Retrieved from http://adt.caul.edu.au/

[28] Lin, Z. J., Liu, M., \& Zhang, X. (2006). The development of corporate governance in China. Asia-Pacific Management Accounting Journal, 1(1), 29-47.

[29] Wu, Y. (2011). Research on the relationship between controlling shareholder and accounting conservatism in China. Applied Mechanics and Materials, 65, 579-584.

[30] Modigliani, F., and M. H. Miller. (1958). The cost of capital, corporation finance and the theory of investment. American Economic Review, 48(3): 261-297.

[31] Watts, R. L., and J. L. Zimmerman, 1986, Positive Accounting Theory (Prentice Hall, NJ).

[32] Loktionov, Y., (2009). Does Accounting Quality Mitigate Risk Shifting? Working paper, Sloan School of Management, Massachusetts Institute of Technology.

[33] Callen, J. L., Chen, F., Dou, Y. and Xin, B., (2010). Information Asymmetry and the Debt Contracting Demand for Accounting Conservatism. Working paper, Rotman School of Business, University of Toronto.

[34] Garcia Lara, J. M., B. Garcia Osma and F. Penalva. (2009). Accounting conservatism and corporate governance. Review of Accounting Studies, 14: 161-201.

[35] Biddle, G. C, G. Hilary and R. S. Verdi. (2009). How does financial reporting quality improve investment efficiency? Journal of Accounting and Economics 48: 112-131.

[36] Francis, J. and X. Martin. 2010. Acquisition profitability and timely loss recognition. Journal of Accounting and Economics 49(1-2): 161-178.

[37] Khan, M., and R. L. Watts. 2009. Estimation and empirical properties of a firm-year measure of accounting conservatism. Journal of Accounting and Economics 48: 132-150.

[38] Richardson, S. A. 2006. Over-investment of free cash flows. Review of Accounting Studies 11: 159-189.

[39] Bushman, R. M. and A. J. Smith. (2001). Financial accounting information and corporate governance. Journal of Accounting and Economics 32: 237-333.

[40] Lambert, R. A., C. Leuz and R. E. Verrecchia. (2007). Accounting information, disclosure and the cost of capital. Journal of Accounting Research, 45(2): 385-420.

[41] Ren, Y. (2014). Corportae governance, conservatism and firm performance:Evidence from China. PhD thesis at School of business, Fauclty of Business and Law, Edith cown University, Perth, Western Australia Cowan University.

[42] Yunos, R. M. (2011). The effect of ownership concentration, board of directors, audit committee and ethnicity on conservative accounting: Malaysian evidence (Doctoral dissertation). Edith Cowan University, Joondalup, Western Australia.)

[43] Yermack, D. (1996). Higher market valuation of companies with a small board of directors.Journal of Financial Economics, 40(2), 185-211.

[44] Brown, L. D. and M. L. Claylor (2004) Corporate Governance and Firm Performance. Gorgia State University, USA. (Working Paper).

[45] Core, J., W. R., Holthausen, and D. Larcker (1999) Corporate Governance, Chief Executive Officer Compensation, and Firm Performance. Journal of Financial Economics 51, 371-406. 
[46] Bollen, K. A. (1996) "An Alternative Two Stage Least Squares (2SLS) Estimator for Latent Variable Equations." Psychometrika, 61, 109-121.

[47] Xiaobao Song, (2015) "Monitoring or tunneling by large shareholders: evidence from China private listed companies", China Finance Review International, Vol. 5 Iss: 2, pp. 187-211.
[48] WALKER, A. M. (2015). The implications of research on accounting. Accounting and Business Research, p. 620-650.

[49] Manuel Illueca, L. N. (2016, February 1). Conditional Accounting Conservatism and Bank Risk Taking. Do changes in the timeliness of loan loss, p. 41. 